\title{
Microelectronics Design in Educational Apps for Technical Education Learning in Pandemic Eras
}

\author{
A. O. Ezeama ${ }^{\text {a }}$, P. I. Obe ${ }^{\text {b,* }}$ R. N. Ezeama ${ }^{\mathrm{c}}$, V. Oguejiofor ${ }^{\mathrm{d}}$ \\ ${ }^{a}$ Department of Mechatronic Engineering, University of Nigeria, Nsukka, Enugu State, NIGERIA. \\ ${ }^{b}$ Department of Industrial Technical Education, University of Nigeria, Nsukka, Enugu State, NIGERIA. \\ ${ }^{c}$ Department of Education Economics, University of Nigeria, Nsukka, Nsukka, Enugu State, NIGERIA. \\ ${ }^{d}$ Department of Mechanical Engineering, University of Nigeria, Nsukka, Nsukka, Enugu State, NIGERIA.
}

\begin{abstract}
In the educational sector where the study was conducted to determine effect of pandemics in the use of microelectronics in design of educational apps for online learning in technical education in Nigeria. The population for the study was 302 people made up of 264 technical college teachers in both public and private schools and 38 school administrators. The instrument for data collection was structured questionnaire. The return rate of the instrument was $96 \%$. Three experts validated the instruments. A pilot study of 10 school administrators and 30 technical college teachers were conducted. Pearson Product Moment Correlation Coefficient was used to test for the reliability. The total reliability coefficient of .79 was obtained for the instrument. Three research questions and three null hypotheses guided the study. Mean and standard deviation were used to answer the research questions, while $t$ test was employed to test the null hypotheses at .05 and .01 levels of significance. Also, MATLAB application was used to give graphical views of critical relations in the study. The major findings were: (1) A good of number of private technical education have ICT facilities and staff than most public technical education schools. (2) There is no significant difference between the use of ICT skills of teachers in the pre-COVID-19 era because the F-tab of 6.64 and 18.0 at $5 \%$ and $1 \%$ levels of significances respectively as against F-cal of 0.0014. (3) There is significant difference on the income of technical education administrators since the introduction of EduApps in teaching and learning because the F-tab of 6.64 and 18.0 at $5 \%$ and $1 \%$ levels of significances respectively as against F-cal of 2.82. It was recommended that technical colleges should be well equipped with Internet of Things facilities and competent technology skilled technical teachers, ICT experts and functional computer laboratory in other to enhance the teaching and learning in technical education.
\end{abstract}

Keywords: microelectronics, technical education, educational apps, coronavirus pandemic

\section{INTRODUCTION}

Microelectronics has to do with knowledge of solid-state physics, microelectronics fabrication, and electronic circuit analysis because it has multidisciplinary approach. References [1, 2] enumerated different simulation software: simple Easy EDA, LT spice and powerful Multisim, Proteus laboratories. The latterare often used to model electronic circuits, which are studied in the course of microelectronics. This investigation has as its major purpose to determine online teaching platforms available for learning in Nigerian public and private technical education vis-a-vis their shortcoming to avert disruptions caused by COVID-19 pandemics. In Nigeria most, private

*Corresponding author (Tel: +234 (0)803 053 7195)

Email addresses: osita.ezeama@unn.edu.ng (A. O Ezeama), pauline.obe@unn.edu.ng (P. I. Obe), ezeamanneka23@gmail.com (R. N. Ezeama), victor.oguejiofor@unn.edu.ng (V. Oguejiofor) technical education centers have embraced online activities more than most public technical education centers because there are limited funds and persistent deficiencies in implementation of online activities in learning. The implication being that these students in public schools currently have no formal learning plans and could be missing learning which demote media competence and brings about educational digital divide. There are short term emergent ICT facilities in the education system that are self-defeating exercise in the long term which this study tents to investigate its economic effect(s) on the technical education administrators.

Urgent calls for entrenchment of suitable technology skills into learning in technical education are eminent, and to bridge educational digital divide that currently exist, and could be worsening with a shift in technical education approaches. Technology skills abound and continues to evolve, but in the capability of one to especially use and apply it in learning to meet the 
global prospect of the Internet of Things (IoTs) that brings about technological innovations and advancements. The Iota has variety of tools which can be downloaded from iTunes or the Google App store to solve some classroom interruption/ challenges in the Nigeria technical education learning. The following are education technology skills: Word Processing Skills, Spreadsheets Skills, Database Skills, Electronic Presentation Skills, Web Navigation Skills, Web Site Design Skills, E-Mail Management Skills, Digital Cameras, Computer Network Knowledge Applicable to your School System, File Management \& Windows Explorer Skills, Downloading Software From the Web (Knowledge including eBooks), Installing Computer Software onto a Computer System, WebCT or Blackboard Teaching Skills, Videoconferencing skills, Computer-Related Storage Devices (Knowledge: disks, CDs, USB drives, zip disks, DVDs, etc.), Scanner Knowledge, Knowledge of PDAs, Deep Web Knowledge, Educational Copyright Knowledge, Computer Security Knowledge [3]. So many educational Apps are available to avert interruption in educational learning and can improve the economy of the school administrators. The Apps which can be applied using video, e-mail, desktop conferencing, online programs for example WebTV and Blackboard, in addition to video conferencing-to teach include: WhatsApp, Instructables, Evernote, Classtree, Schoolgy, Oxford dictionary, Google classroom, Alison, SAFSMS Mobile, Kahoot, Google forms, Udacity, BrainScape, Ready4SAT, Photomath, edX, ScholarX, Coursera, BulbApp, Khan Academy, Schoolgate, MobieClassroom, Seesaw, National Open University, Zoom(Google play store), Edmodo, Google Hangouts, Duolingo, Quizlet, Seesaw learning Inc, Udemy, Brainpop, Toontaastic 3D, BoboExplores light, Pages, imovie, Massive open online course(MOOC), MIT open coureware, Skype, Google Earth, jitsi meeting, WebRoom, MozillaHubs, BigBlueButton, OpenBroadcaster Software, WizIQ online software, Whereby, GoBrunch, Remotehour, Callaba, Xroom, EduMobile, uLesson, UCreate-Hub, Android App, etc [4-8].

The purpose of technical education is principally for the training of skilled worker for the world of work. In technical education where metalwork is offered as a trade, metalwork according to Ogbonna [9] is the application of scientific knowledge in the activity of making objects - out of metal in an artistic and skillful way. Again, the study of metal work technology exposes students to tools, materials, operations and processes in metal working trade areas in industries to showcase skill [10]. Obe [11] has opined that metalwork technology involves the process of shaping or producing metal products out of metal where the art or skill of using metallic materials in the production of metal product. It is obvious that graduates of technical education will perform better if they are well trained in their trade areas [12]. Thus, the gap between traditional automotive technology (TAT) and modern automotive technology (MAT) can be easily closed through the skill improvement and professional technical education teacher development for better performance of their graduates [12].

The global lockdown caused by Coronavirus disease (COVID-19) has affected the educational sector and all human endeavors' in no little way in Nigeria. Coronaviruses are a large family of RNA viruses that infect birds and many mammals including humans [13]. These viruses cause illnesses that range from common cold to more severe respiratory diseases and rarely gastroenteritis. Coronavirus disease (COVID-19) is caused by an emerging strain of coronavirus (SARS-Cov-2) that has not been previously identified in humans, belonging to the same family of viruses responsible for severe acute respiratory syndrome (SARS) and Middle East respiratory syndrome (MERS), for which zoonotic and person- to-person transmission have been confirmed. Since the declaration of COVID-19 as a Public Health Emergency of International Concern (PHEIC) on January 30,2020 , the Nigerian Government has closely monitored the ongoing outbreak which originated in Wuhan, China [13]. Coronavirus pandemic could reshape the educational system of the world considering the lockdown approach which made teachers and students to stay safe at home using online technology skills to limit the disruption of education and promote participation in teaching and learning, but have far-reaching economic and societal consequences $[14,15]$. Approximately 1.725 billion learners, including those in technical education, are currently affected due to school closures in response to the pandemic as reported by UNICEF monitoring, that 186 countries are currently implementing nationwide closures and 8 are implementing local closures, impacting about 98.5 percent of the world's student population [15]. In some parts of Nigeria, access to education was provided through solar radio program Lumpsum-National and community radio airtime-Procurement of radios, recorders and other radio equipment with other options through online internet applications using smart phones, tablets, or laptop to avert education disruption [16]. There was some kind of monitoring using Response Monitoring Tool/5W Matrix (Who is doing What, Where, When and for Whom) for monitoring education sector partners activities under the current COVID-19 contingency response and the progress of programme implementation and ensure alignment with the (to be) amended Humanitarian Response Plan (HRP) to see that students are deprived of learning in any form [16]. Lateef and Samuel [17], has put together the global health hazards and economic Impacts of COVID-19 and stated the cost of the outbreak at about US $\$ 2$ trillion in 2020. Most central banks, finance ministries and independent economic experts around the world have taken solace in the prediction that the impacts might be sharp but short-lived, and economic activities would return to normal thereafter and there is this line of thought of the events that shaped the 2007 
global financial crisis [17]. Other previous pandemics that made teachers and learners use new technologies to adapt when schools were closed in response to outbreaks involving the $\mathrm{H} 1 \mathrm{~N} 1$ influenza virus: the 'swine flu' that afflicted many in Mexico about six years ago; and an earlier outbreak of 'bird flu' in China, then outbreak of the Ebola virus in West Africa making it clear the use technology skills to help our students while our schools are closed [6]. COVID-19 pandemic should further offer the Nigerian economic managers and policymakers that the one-tracked, monolithic reliance on oil is failing and diversification priorities to alternative sectors such as agriculture, solid minerals, manufacturing and services sectors (education and technology), should be further intensified by innovating through adaptive learning technology majorly in the service sectors [18-20]. Even before the outbreak, the outlook for the world economy-and especially developing countries like Nigeria-was fragile, as global GDP growth was estimated to be only 2.5 percent in 2020. While many developing countries have recorded relatively fewer cases-Nigeria currently has 238 confirmed cases and 5 deaths as of this writing - the weak capacity of health care systems in these countries is likely to exacerbate the pandemic and its impact on their economies [19, 20]. In COVID-19 pandemic Nigeria Government has boasted it's Public Private Partnership, and in conjunction with management of School Media (a role model in the adoption of technology in education in Africa and a reference point for all edu-tech stakeholders since 2013), created two telegram groups, code named "Unity Schools Virtual Learning (Senior School) and Unity School Virtual Learning (Junior School) to distribute starter packs and class codes instructions to students and selected teachers for the programme, to run on a virtual classroom platform called Edmodo, while Telegram will be used as a clearing house to organize the students and share critical updates on the programme [21,22]. Also, experts from Skool Media's subsidiary, EDUFIRST.NG have built a robust archive of learning materials and video resources weaved around the approved curriculum and scheme of work of the National Education Research Development Council, NERDC. The resources are being currently accessed from EDUFIRST TV - a YouTube Channel,and executed Augmented and Virtual Reality, AR/VR, programmes for practical sessions for science students both in the colleges and the Federal Science and Technical Colleges, FSTC providing a platform for the Nigerian child to compete globally [21-23]. Recently, as reported in 2016 by [23] that Coscharis Technologies (a leading ICT solutions company) in partnership with Cinfores and ASUS, has developed and launched Edu-Mobile(mobile learning programme that integrates a typical school environment into an App so students and teachers have round-the-clock, real-time access to learning),embedded in ASUS mini-pads with Brain Friend software, which is Nigeria's first mobile school targeted at primary and secondary school students and teachers.

World Bank stated that the outbreak of the virus and lockdowns at the national level could be used as the best test for the education technology interventions for learning using the IOTs [24]. Unfortunately, in many nations, Students and education systems are on the front line of many such pandemics,so ICT will maybe put to their real test globally. In West Africa as reported by [25], education technology start-up uLesson App has created a learning application for secondary school/technical college students, designed to help them master different subject matters with ease and maximise their academic potential. Skool Media, a Nigerian Edtech startup focused on retooling the country's education system and providing a platform for the Nigerian child to compete globally, is set to launch UCreate-Hub, a new innovative space where kids and teenagers (especially science and technical college students) are inspired to innovate, create and collaboratively learn coding, 3D printing, robotics, and artificial intelligence [26].

In Nigeria, the following Apps are commonly used for teaching and learning in technical colleges during the pandemic: WhatsApp, Instructables, Evernote, Classtree, Google classroom, Alison, SAFSMS Mobile, Kahoot, Udacity, Photomath, Coursera, BulbApp, Schoolgate, MobieClassroom, Zoom (Google play store),Edmodo, Skype, MozillaHubs, WizIQ online software, EduMobile, AndroidApp, uLesson and UCreate-Hub. However, WhatsApp a non-classroomplatform was observed to pose some challenges because of irregular posts by students despite warnings. Apps like Google classroom, Zoom, Edmodo, Skype, Edu-Mobile and uLesson seem to have some likeable features among technical college teachers and students. Also, some private technical colleges and some public in partnership with corporate bodies were able harness of the following Apps due to their uniqueness to technical trade subjects: MozillaHubs (3Dcompliant views), WizIQonline software and Alison (create online trade subject and start teaching instantly), Kahoot(has skills to make a game from scratch) while Instructables (classroom maker project that help students create something awesome and share ideas, and teachers can upload their instructions), SAFSMS Mobile(help keep attendance, grades and class notes than the easily misplaced notebooks), Google classroom(help teachers to distribute and grade assignments as well as organize all class materials on Google drive),Classtree(notifies parents of the logistics of an upcoming field trip), UCreate-Hub(help students create and collaboratively learn coding, 3D printing, robotics, and artificial intelligence),Android App(use for science subject study and provide interactive text, illustration and video), and Evernote (allow teachers share notes, assignments and projects with students) help technical college teachers and administrators in students evaluations and school management. 


\subsection{Statement of the Problem}

The technology skill attainment in a competency-based trade subjects in technical education is ascertained through modern technology competence of teachers and competency-based assessment process for students to meet with demands of the global world of work. Occupational areas offered in technical education in Nigeria as trade subjects are over forty which are designed to equip student with skills necessary for securing paid employment in industries or being self-employed [27]. Therefore, students of the technical education are expected to be equipped with job skills to enable them perform and progress in the occupational trade areas. However, it has been revealed from research studies that in Nigeria, the training of technical personnel has witnessed formidable challenges ranging from poor funding to inadequate facilities both quantitatively and qualitatively, non-availability of adequate human capacity, brain drain and poor staff training and retention profiles which has deprived graduates a lot [28]. Also identified, were wrong method of assessing and use of assessment instruments in assessing the skills of the students, weak university/industry partnership, defective curricula, traditional approach to teaching, poorly equipped laboratories, poorly monitoring standards for the training of prospective technologists and an inadequate ICT environment to assist in the standard modern teaching and learning in technical education in Nigeria [28, 29]. The National Technical Certificate (NTC) and the Advanced National Technical Certificate (ANTC) examination conducted by NABTEB for assessing metalwork technology are mere assessment of knowledge (cognitive) and the finished products (psychomotor) neglecting the process skills (psychomotor) and the whole affective (attitude) meaning that the scores and grades assigned to students are not the true representative of their performances since the evaluation did not cover all expects of the competency-based assessment (knowledge, skill and attitude) so the process has made graduates lack sufficient skills and yet have good grades in their assessments, resulting to unemployment, non-sustainability of employment and non-self-reliance but trainable in modern technology skill operation [29]. This study then seeks to assess technical education teachers who lacking in the use modern technology skills to be equip in order to improve professionally and administrators are to harvest the quantum economic opportunities in the usage of relevant educational Apps to showcasing their schools and in learning. Technical education teachers in Nigeria are still faced with problems in Its platform applications due to: power challenges, Network challenges, inadequate internet facilities, much traffic, very fast lesson schedules, unreasonable interruptions from students, inadequate ICT capacity building for teachers, but they are expected to be technologically literate in order to help avert disruptions in the educational sector. Technical education teachers as trainers should be able to bridge the gap between traditional and modern technology for skill improvements, competency and professional development of both trainers and learners [30].

\subsection{Purpose of the Study}

The general purpose of the study is to investigate and determine online teaching platforms available for learning in Nigerian public and private technical education vies a vies their shortcoming to avert disruptions caused by COVID 19 pandemics.

Specifically, the study seeks to:

1. Determine the benefits of ICT skills in technical education in order to avert learning disruption in pre COVID-19 era.

2. Determine the economic effect of using EduApps on technical education administrators in teaching and learning.

3. Determine the extents of technical education teachers' involvement in the useIOT skills in teaching in order to avert learning disruption caused COVID-19 pandemic.

\section{METHODOLOGY}

\subsection{Research Questions}

The following research questions were raised to guide the study:

1. What are the benefits of ICT skills in technical education in order to avert learning disruption in pre COVID-19 era?

2. What are the economic effect of using EduApps on technical education administrators in teaching and learning?

3. What are the extents of technical education teachers' involvement in the useIOT skills in teaching in order to avert learning disruption caused COVID-19 pandemic?

\section{RESULTS}

\subsection{Research Hypothesis}

The null hypothesis formulated to guide this study was tested at 0.05 level of significance thus:

1. There is significant difference between the mean scores in the use of ICT skills in technical education by teachers in the Pre COVID19 era.

2. There is no significant difference between the mean scores on the income of technical education administrators since the introduction of EduApps in teaching and learning.

3. There is significant difference between the mean scores of capacity building needs of technical education teachers in the use of IOT skills to avert learning disruption caused by COVID-19. 
Table 1: Mean ratings of teachers' competency levels in the eras (D1, D2 and D3) scores in technology skills operations.

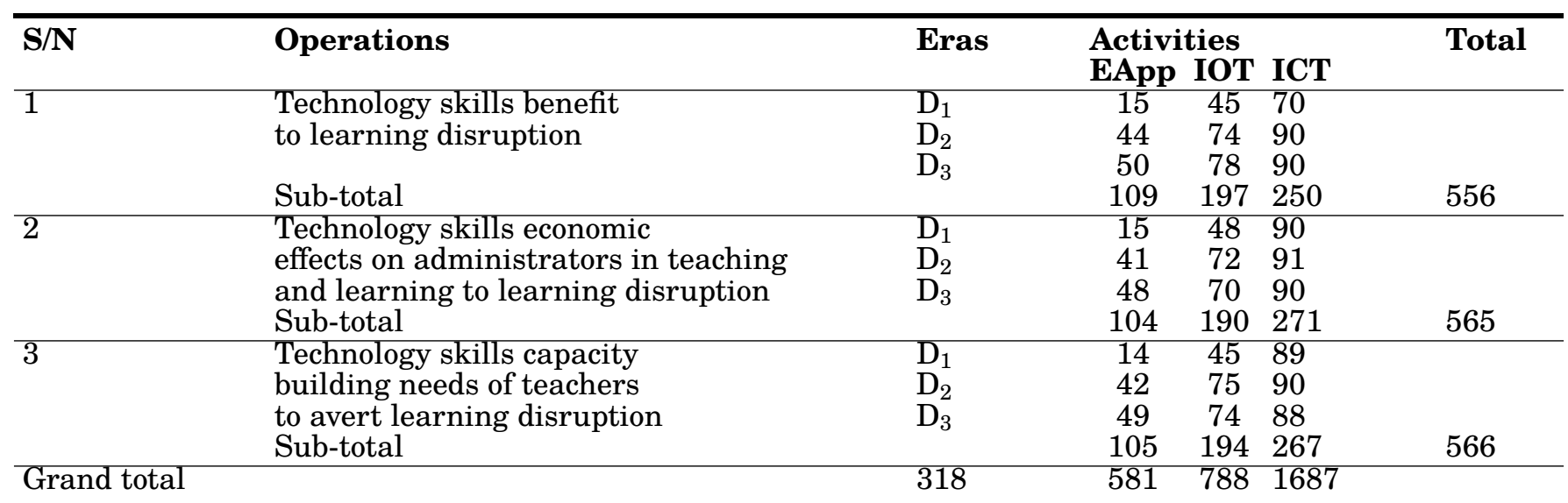

Keys: three technology skills operations. D1 = pre COVID 19 Era. D2 = COVID 19 Era. D3 = post COVID 19

Era. Activities on EApp (education Apps usage), IoT(internet of things) and ICT(information communication technology)

\subsection{Research Method}

This study investigated and determined online teaching platforms available for learning in Nigerian public and private technical education vis-a-vis their shortcoming to avert disruptions caused by COVID-19 pandemics. The technical education operations face severe challenges including high poverty levels, low enrollment, gender disparities, poor quality and relevance, poor infrastructure, non-expanding of technical and vocational opportunities, relevant improvement plans and teacher professional development to the needs of industry and local communities and learning conditions; students' low access to internet technology according to, [31, 32]. Studied in the field with 264 teachers and 38 administrators are: on ICT facilities in the technical education, how the administrators maintain the facilities and teacher's capacity in use of the technology skills in the teaching and learning. We gathered their responds through a checklist. The checklist contains some statements; teachers and administrators are asked to choose whether they "mostly needed", "needed", "partially needed", or "not needed" with the items on instrument. The basic assumptions for the given model of the factorial design did estimates of the parameters of the given model, test the hypothesis on two-way classified data with some observations per cell and the table of observations were displayed as suggested by [33]. The finding shows that there is no significant difference between uses of ICT facilities in the technical education, how the administrators maintain the facilities and teacher's capacity in use of the IOT skills and EduApps in the teaching and learning thus; the null hypothesis is rejected since the p-value is less than 0.05.Teachers' technology activities skills differ based on their individual commitment to teaching, available facility and ICT competency. This agrees with study by [34] on "the Use of Innovative Learning Methods in the System of Modern Economic Educa- tion in the Russian Federation", noted that a more thorough implementation of the theoretical background of the education process can be achieved by combining innovative and conventional methods to bring the education system of the Russian Federation in compliance with the modern requirements.

The data presented in Table 1 showed that mean scores of activities performed had minimum value of 14 and maximum value of 91 on entire operations of teachers and administrators. The result of the study show that activities performed within (D1, D2 \& D3) by teachers are reliable and efficient during the determination that had value of 1687 as grand total sum of the scores of the ability levels based on different eras.

\subsection{Testing of Hypotheses}

3.3.1. There is significant difference between the mean scores in the use of ICT skills in technical education by teachers in the Pre COVID-19 era.

Decision rule: In Table 2, F-cal of 2.82 for activities performed show that there is no significant difference between the use of ICT skills of teachers in the pre COVID-19 era because the F-tab of 6.64 and 18.0 at $5 \%$ and $1 \%$ levels of significances respectively are greater than F-cal thus the null hypotheses is accepted.

\subsubsection{There is no significant difference between the mean scores on the income of technical education administrators since the intro- duction of EduApps in teaching and learn- ing. \\ Decision rule: F-cal of 0.0014 for operations per-} formed show that there is significant difference on the income of technical education administrators since the introduction of EduApps in teaching and learning because the F-tab of 6.64 and 18.0 at $5 \%$ and $1 \%$ levels of significances respectively are greater than F-cal thus the hypotheses is accepted. 
Table 2: Analysis of variance of data on Table 1, showing Sources of variation, degree of freedom, sum of squares, mean squares and F-values (F-calculated \& F-tabular or critical).

\begin{tabular}{|c|c|c|c|c|c|}
\hline Source of variance & df & $\mathbf{S S}$ & Ms & f-cal & F-Tab \\
\hline Technology skills operations (TSO) & 2 & 6.0 & $3 * *$ & .0014 & $\begin{array}{cc}5 \% & 1 \% \\
6.64 & 18.00\end{array}$ \\
\hline Teachers Activity level (TAL) & $\overline{2}$ & 12331 & $6165.5 * *$ & 2.82 & 6.6418 .00 \\
\hline Experimental Error (EE) & 4 & 8747 & $2186.8 * *$ & 0.59 & $3.63 \quad 6.42$ \\
\hline Sampling Error (SE) & 9 & 332441 & 3693.44 & & \\
\hline Total & 17 & 54325 & & & \\
\hline
\end{tabular}

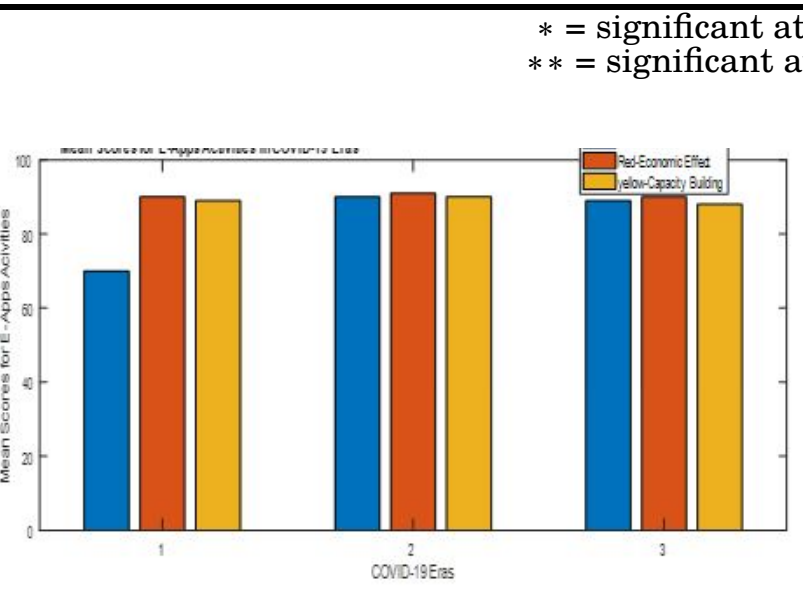

(a)

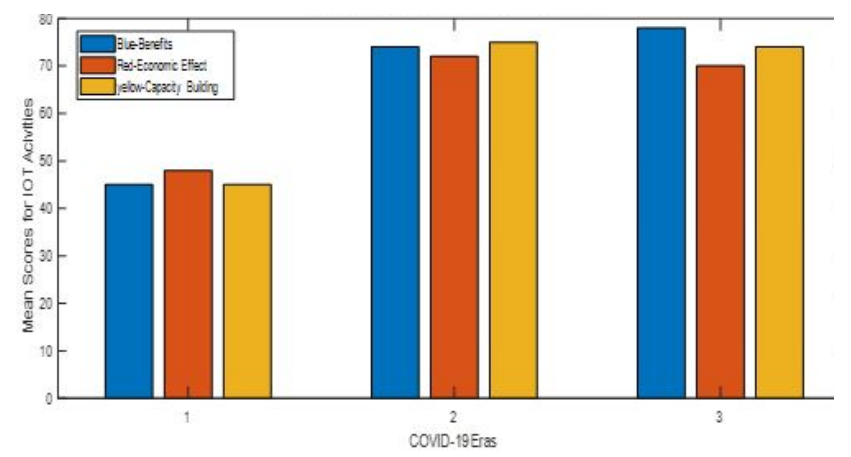

(b)

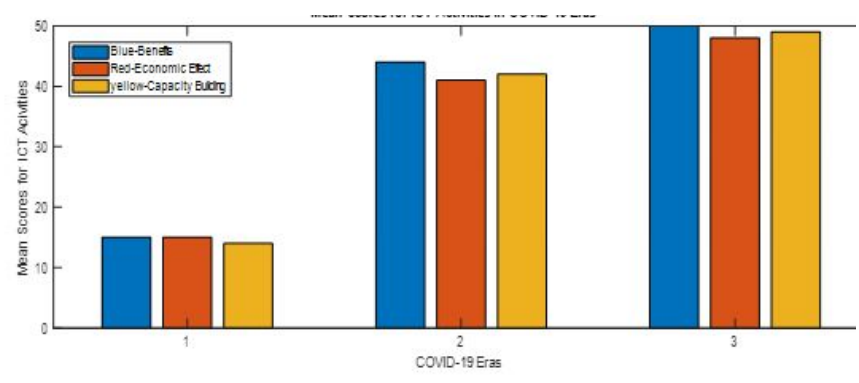

(c)

Figure 1: Graphical views of skill operations of COVID pandemic eras against activities

\subsubsection{There is significant difference between the mean scores of capacity building needs of technical education teachers in the use of IOT skills to avert learning disruption caused by COVID-19.}

Decision rule: F-cal of 2.82 for activities performed show that there is no significant difference in the use of IOT skills to avert learning disruption caused by COVID-19 because the F-tab of 6.64 and 18.0 at $5 \%$ and $1 \%$ levels of significances respectively are greater than F-cal thus the null hypotheses is accepted.

\section{DISCUSSION AND FINDING}

However, it has been revealed that graduates of technical education are not able to perform the competences in their occupational trade especially because of skills inadequacy and due to the problem of curriculum content in educational institutions [35]. Consequently, they are neither employable by the industry nor self-employed thus endangering the society with unemployed people which causes problems in the society. Now the situation of conventional technical education apprenticeship system in the informal sector which is most available, were observed to lack the modern technologies required to improve skills remains more problematic in this pandemic era [36]. Schools that have always been ICT compliant were able to transit to adopting technology skills in teaching and learning more than those that have never been ICT compliant at this time, as indicated in Fig 1 (a, b, and c). A good of number of private technical education have ICT facilities and staff than most public technical education schools. It was discovered as observed by some teachers, that what started as daily classes reduced to three classes a week due to Internet issues and parents being inconvenienced by their wards using their devices so frequently. Also, many teachers were of the view that adopting technology platforms for learning is most cost effective and challenging but school administrators are to encourage teacher capacity building and maintain the e-learning set even when normal physical classes resume. Use of technology skills in teaching and learning will benefit teachers and administrators of technical education even when the pandemic will be over. Graduates of technical education will be competent to showcase their skills the world of work if 
they undergo technical training in a good state of art technical schools in Nigeria.

\section{CONCLUSION}

The Technical education in Nigeria are designed and aimed at providing skills necessary for securing employment in the industry or be self-employed, hence, the graduates of technical college are expected to be equipped with modern job skills to enable the individual perform and progress in the chosen trade and in entering into employment. Insufficient modern skills acquisition in technical education was noted before the COVID-19 pandemic and the deployment into use of EduApps platforms in teaching and learning necessitated the study.

\section{RECOMMENDATIONS}

1. The Federal Ministry of Education department in charge of technical education should liaise with private and public technical schools' administrators to see that use of EduApps in learning is fully implemented in schools' curriculum.

2. The examination bodies in charge of conducting and organizing examinations for the technical colleges (NABTEB) should integrate the use of EduAppsin their examination for certification of student in technical colleges.

3. The NBTE should develop and integrate the use of EduApps into the curriculum of Technical Colleges for training student.

4. The Nigerian Educational Research and Development Council should develop and integrate the use of EduApps into the vocational curriculum of technical colleges under the Council.

5. The technical education teachers should endeavor to build up their capacity in the use and application of EduApps, Internet of things, ICT ability in order to be relevant.

\section{References}

[1] M. E. Herniter, Multisim: the modern system of computer simulation and analysis of schemes of electronic devices. Moscow: Izdatelskiydom DMK-press, 2009.

[2] A. A. Shegal, "The application of multisim software system for designing microcontrollers laboratory workshop," Ekaterinburg :Izd-vo Ural. Unta., 2014.

[3] T. Laura. (2005) 20 technology skills every educator should have. [Online]. Available: https://thejournal.com/articles/2005/06/01/20technology-skills-every-educator-should-have.aspx

[4] O. Rahamh. (2017) 18 best educational apps for educators and students. [Online]. Available: https://safsms. $\mathrm{com} / \mathrm{blog} / 16$-best-educational-apps-teachers-students/

[5] A. Fran. (2020) Oxfordtefl teacher training. [Online]. Available: https://www.oxfordtefl.com/blog/9-freealternatives-to-zoom-for-getting-your-classroom $\backslash$ online

[6] M. Trucano. (2014) Education and technology in the age of pandemics (revisited) world bank blogs from word bank organization. [Online]. Available: https://blogs.worldbank.org/edutech/educationtechnology-age-pandemics-revisited
[7] M. Burns. (2020) School interupted: 4 options for distance education to continue teaching during covid 19. [Online]. Available: https://www.globalpartnership.org/blog/schoolinterrupted-4-options-distance-education-continueteaching-during-covid-19

[8] H. H., U. Budijanto, J. Wirjawan, and E. Pratidhina, "Development of Android App to Assist High School Students in Learning Physics Quantities and Measurement Principles," TEM Journal, vol. 9, no. 1, pp. 292295,2020

[9] G. N. Ogbonna, "Development and validation of instrument for assessing practical skill in general metal work of technical college students," Unpublished, Department of Industrial Technical Education. University of Nigeria Nsukka, 2016.

[10] B. A. Ogwo, "Effect of meta-learning instructional strategy on students' achievement in metal work technology," Journal of Education Department of Vocational Teacher Education University of Nigeria, Nsukka, vol. $17,2006$.

[11] P. I. Obe, A. O. Ezeama, T. C. Ogbuanya, and E. O. Ede, "Development and validation of competency- based instrument for assessing mechanical metalwork technology operations of technical colleges," Nigerian Journal of Technology, vol. 38, no. 4, pp. 884-895, 2019.

[12] A. O. Ezeama and V. I. Oguejiofor, "Skill improvement needs of motor vehicle mechanics teachers in technical institutions," International Technology Research Journal, vol. 4, no. 1, pp. 14-19, 2016.

[13] (2020) National Interim guidelines for Clinical Management of COVID-19 version 1 on $14 / 03 / 2020$ by the Nigerian Center for Disease Control (NCDC). [Online]. Available: https://www.google.com/search? client=firefox- $b-d \& q=n c d c+$ covid $+19+$ update

[14] T. Gloria and E. Diana. (2020) 3 Ways the corona virus pandemic could reshape education. China Daily CDIC. [Online]. Available: https://www.weforum.org/agenda/2020/03/3ways-coronavirus-is-reshaping-education-and-whatchanges-might-be-here-to-stay/

[15] (2020) Impact of the $2019-20$ COVID Pandemic on education. WIKIPEDIA the free encyclopedia. [Online]. Available: https://en.wikipedia.org/wiki/Impact_of_the_2019\% E2\%80\%9320 coronavirus pandemic on education

[16] P. Amani and T. Odeka. (2020) Nigeria education in emergencies working group. [Online] Available: $\quad$ https://reliefweb.int/sites/reliefweb. int/files/resources/nigeria_education_sector_covid19_response_strategy_north_east_.pdf

[17] O. A. Lateef and C. G. Samuel. (2020) Implication of covid 19 on nigeria economy. [Online]. Available: http://cseaafrica.org/the-implication-of-covid19on-the-nigerian-economy/

[18] P. K. Ozili, "COVID 19 Pandemic and Economic Crisis: the Nigerian Experience and Structural Causes," SSRN Electric Journal, 2020.

[19] A. Adeniran and T. Obiakor. (2020) Risk control measures threaten to deepen nigeria education crisis. [Online]. Available: http://cseaafrica.org/covid-19-risk-control-measuresthreatens-to-deepen-nigerias-education-crisis/

[20] C. Onyekwena and M. A. Ekeruche. (2020) Impact of covid 19 outbreak on the nigerian economy. [Online]. Available: https://www.brookings.edu/blog/africa-infocus/2020/04/08/understanding-the-impact-of-thecovid-19-outbreak-on-the-nigerian-economy/

[21] A. Wahab. (2020, April) COVID-19: Skool Media broadens E-Learning in Unity Schools with Edmodo app. [Online]. Available: https://www.vanguardngr.com/2020/04/covid-19skool-media-broadens-e-learning-in-unity-schoolswith-edmodo-app/

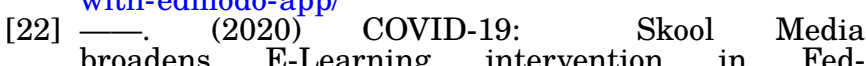
eral Unity Schools. [Online]. Available: https://techpoint.africa/2020/04/20/covid-19-skoolmedia-broadens-e-learning-intervention-in-federalunity-schools/ 
[23] O. Kolawole. (2020) How Nigeria is handling interruption in school activities. [Online]. Available: https://techpoint.africa/2020/04/15/pandemicand-academic-activities/

[24] R. Adekule. (2016, March) Nigeria's first mobile school apps ready for use. [Online]. Available: https://guardian.ng/features/education/nigeriasfirst-mobile-school-apps-ready-for-use/

[25] S. Onyekwelu. (2020, March) Nigeria's uLesson app to ease learning for secondary school students. [Online]. Available: https: //businessday.ng/education/article/nigerias-ulessonapp-to-ease-learning-for-secondary-school-students/

[26] A. Iyanda. (2020) Nigerian startup introduces special hubs to promote technical skills in schools. [Online]. Available: http://venturesafrica.com/nigerian-startupintroduces-special-hubs-to-promote-technical-skillsin-schools/

[27] (2019) Technical education and its challenges in Nigeria in the $21^{\text {st }}$ Century. [Online]. Available: https://net.nbte.gov.ng/sites/default/files/202002/2019\%20DIRECTORY.pdf

[28] V. O. Uwaifo. (2020) Approved and Accredited Technical Colleges (TVET Institutions). [Online]. Available: https://www.researchgate.net/publication/ 228374887_Technical_education_and_its_challenges_ in Nigeria_in_the_21_st_Century

[29] NBTE, "Report on performance of students in ntc examination," NABTEB Press, Benin, Tech. Rep., 2014.

[30] A. O. Ezeama, P. I. Obe, M. A. Aniago, and E. O. Ede, "Comparative analysis of diagnostic application of autoscan tools on vehicle systems," Nigerian Journal of Technology, vol. 36, no. 2, pp. 523-527, 2017.

[31] S. Morten and S. Subrata, "Education in nigeria," Global partnership for Education world Bank Project Appriasal document. Compiled by UNESCO Institute for Statistics from official response from surveys and reports provide by education authorities in each country, 2015, https://www.globalpartnership.org/wherewe-work/nigeria.

[32] "Challenges of online teaching (and how to rise above them)," (C) 2020 3P Learning - The teaching moments that inspire learning, 2020, all Rights Reserved.

[33] M. Plonsky, "Analysis of variance-two way," Psychological Statistics, 2017.

[34] P. Aleksey, A. Mikhailova, A. Gryaznukhin, V. Movchun, O. Dvoryankin, and I. Natalia, "The Use of Innovative Learning Methods in the System of Modern Economic Education in the Russian Federation," TEM Journal, vol. 9, no. 1, pp. 304-308, 2020.

[35] C. S. Ayonmike, "Addressing the skills need in Nigeria oil and gas industry through technical vocational education (TVET)," Nigerian Vocational Association Journal, vol. 17, no. 1, pp. 102-111, 2012.

[36] M. T. Oladejo, "Work Socialisation and Apprenticeship System in Garment Industry of Ibadan 1930s to 1970s," in Dynamics of Culture \& Tourism in Africa: Perspectives on Africa's Development in the 21st Century, K. C. Nwoko and O. M. Osiki, Eds. Ilishan-Remo: Babcock University Press, 2015, pp. 561-580. 